\title{
Continuous affinity-based selection: rapid screening and simultaneous amplification of bacterial surface-display libraries
}

\author{
Dipak PATEL*, Srdjan VITOVSKI*, H. Jennifer SENIOR*, Michael D. EDGE $\dagger$, Robert C. HOCKNEY $\dagger$, Michael J. DEMPSEY $\ddagger$ \\ and Jon R. SAYERS ${ }^{\star 1}$ \\ *Division of Genomic Medicine, University of Sheffield, Royal Hallamshire Hospital, Sheffield S10 2RX, U.K., †AstraZeneca, Mereside, Alderley Park, \\ Macclesfield SK10 4TG, U.K., and \$Department of Biological Sciences, Manchester Metropolitan University, Manchester M1 5GD, U.K.
}

A new method for continuous biopanning has been developed. We have combined the power of affinity chromatography with the fecundity of bacteria in a unique process that mimics clonal selection. Mixed populations of bacteria were applied to a fermenter containing the immobilized ligand of interest. Bacteria retained in this affinity fermenter were allowed to grow under continuous washout conditions, such that weakly bound organisms were selectively lost. Those initially rare founder bacteria expressing a receptor for the immobilized ligand $(\mathrm{R}+\mathrm{ve})$ were thus enriched and amplified simultaneously. From an initial culture containing $1 \times 10^{10} \mathrm{R}$ - ve cells spiked with fewer than 30 $\mathrm{R}+$ ve bacteria $\left(<1\right.$ in $\left.10^{8}\right)$, final ratios of $\mathrm{R}+\mathrm{ve} / \mathrm{R}$ - ve bacteria as high as 1 in 12 were observed, representing an enrichment factor of 55 million-fold. This technology has considerable potential for rapid screening of bacterial surface-display libraries and in facilitating directed-evolution studies.

Key words: affinity chromatography, Escherichia coli, lamB, phage lambda receptor, peptide library.

\section{INTRODUCTION}

The identification of protein or peptide sequences capable of binding a particular target molecule is of considerable importance in many areas of biology and medicine. The production of monoclonal antibodies is one such example [1]. In this case an antigen is first injected into animals where a polyclonal response may be mounted. A small proportion of the B cells present may bind antigen and undergo clonal expansion. Hybridomas can be produced and screening protocols applied, leading to the production of monoclonal antibodies with the required binding characteristics. This approach, though highly successful, can take several months and sometimes fails when the antigen is poorly immunogenic. Phage display of peptide and antibody libraries [2,3] can provide binding entities on a significantly shorter time scale. Phage-display libraries are screened by iterative 'biopanning'; cycles of affinity chromatography (enrichment), elution and amplification. However, we wished to develop a biopanning system capable of continuous enrichment and simultaneous amplification of live bacteria displaying a particular surface-exposed protein.

Display on the bacterial cell surface has already been exploited in the development of live bacterial vaccines, in selection of peptide and antibody libraries, and in the preparation of microbial biocatalysts [4-6]. Bacteria such as Escherichia coli possess many ligand-specific outer membrane receptors that function in the transport of substrates into the cell [7]. Immobilized forms of these ligands have been used as affinity media to retain live bacteria in batch-enrichment processes [8,9]. Iterative application of such techniques allows the selective recovery of rare organisms from a larger mixed population.

In our studies, we hoped not only to isolate rare or minor subpopulations that differ in surface-receptor characteristics from the total pool of cells, but to enrich and amplify simultaneously for the isolated sub-populations. We wished to develop a continuous culture system for the rapid isolation/screening and amplification of cells expressing a valuable protein receptor on their outer membrane. We used the LamB (starch-lambda receptor) protein [8] of $E$. coli to develop our model process. lamB encodes the $E$. coli maltoporin, an outer membrane protein (OMP) involved in the transport of maltose and maltodextrins across the outer membrane, and is also the receptor for phage lambda attachment [10-12]. Expression of the $\operatorname{lam} B$ gene in $E$. coli mediates host binding to soluble and immobilized starch [8]. In contrast, strains not expressing the $\operatorname{lam} B$ gene fail to adhere to the immobilized starch. Mixed cultures of known ratios of two strains, differing only in their ability to adhere to immobilized starch, were applied to a fermenter containing the immobilized starch. A continuous supply of fresh media was applied to this affinity fermenter to remove transiently or weakly bound cells yet simultaneously allow growth of those cells tightly bound to the matrix. After continuous selection and amplification on the affinity fermenter, the bound cells were eluted with soluble competitive ligand. The power of this technology for the continuous biopanning, with simultaneous amplification, of bacteria expressing a desired binding-protein is demonstrated.

\section{MATERIALS AND METHODS}

\section{Construction of plasmid}

All DNA manipulations were carried out using standard methods. The plasmid pTF152 [13], a pUC derivative carrying a $\operatorname{lam} B$ gene, was used as the parent plasmid. As this plasmid conferred on the recipient only modest levels of binding to starch, we increased expression by constructing a stronger

Abbreviations used: CABS, continuous affinity-based selection; OMP, outer membrane protein; R - ve, receptor negative; R + ve, receptor positive; SMM, supplemented minimal medium

1 To whom correspondence should be addressed (e-mail j.r.sayers@sheffield.ac.uk). 
promoter using a degenerate promoter cassette (consisting of two partially complementary oligonucleotides (DP1, 5'-TTTAGNNNACAATTCTCTCGAAATCTAGTATAMTATATACATAT-3', and DP2, 5'-CTAGATATGTATATAKTATACTAGATTTCGAGAGAATTGTNNNCTAAAAGCT-3') cloned upstream of the $\operatorname{lamB}$ gene into the $S a c \mathrm{I} / \mathrm{Xba \textrm {I }}$ double-digested plasmid pTF152. A StuI fragment of plasmid pACYC177 [14,15] carrying the aminoglycoside phosphotransferase gene was cloned into the filled EcoRI site of the plasmid described above to provide an alternative antibiotic-resistance marker. Transformants were selected phenotypically for their ability to confer constitutive binding to starch-Sepharose and resistance to kanamycin. Subsequent work was carried out using one such transformant, pCELBK1. The constitutive promoter was sequenced and the -35 and -10 elements were determined as TCAACA and TATAAT respectively.

\section{Bacterial strains and culture conditions}

Development of the starch-mediated model selection system described here was established with $E$. coli $\mathrm{K}-12$ strains. Strain SF46s \{araD139 flbB5301 mals::Tn10 F8[(mals-phoA)3-9(Amp)] phoA8 ptsF 25 rbsR relA1 rpsL150 (argF-lac) U16\} was kindly supplied by Dr W. Boos, University of Konstanz, Konstanz, Germany. This strain binds weakly to starch affinity columns (see Table 1 below) and was considered as receptor negative ( $\mathrm{R}-\mathrm{ve}$; it did not constitutively express LamB protein at levels capable of conferring binding to immobilized starch) and is resistant to up to $200 \mu \mathrm{g} / \mathrm{ml}$ ampicillin. A plasmid (pCELBK1) constitutively expressing $\operatorname{lam} B$ (receptor positive, $\mathrm{R}+\mathrm{ve}$ ) and conferring kanamycin resistance on the host was transformed into SF46s. Bacterial cultures were grown at $37^{\circ} \mathrm{C}$ in liquid culture (rich $2 \times \mathrm{TY}$ media), harvested by centrifugation and resuspended in minimal medium A [16] with $0.2 \%$ glycerol as a carbon source, further supplemented with $0.5 \%$ (w/v) casamino acids and $100 \mu \mathrm{g} / \mathrm{ml}$ ampicillin (supplemented minimal medium, SMM), before experimental use. Precultures of pure SF46s(pCELBK1) were grown as above but supplemented with $50 \mu \mathrm{g} / \mathrm{ml}$ kanamycin.

\section{Preparation of affinity matrices}

The cross-linking of starch and dextran was adapted from methods described previously $[8,17]$. Soluble potato starch (catalogue no. S-2630) and dextran (41600 Da; catalogue no. D-4133) were purchased from Sigma. Briefly, $10 \mathrm{~g}$ of Sepharose 6B-100 beads (Sigma) were washed in $500 \mathrm{ml}$ each of distilled water and $0.6 \mathrm{M} \mathrm{NaOH}$. The beads were suspended in $10 \mathrm{ml}$ of homogeneous 1:1 mixture of $0.6 \mathrm{M} \mathrm{NaOH}$ and butane-1,4-diol diglycidyl ether (bis-oxirane), and incubated for $8 \mathrm{~h}$ at room temperature with mixing on a roller mixer. After activation with bis-oxirane, the beads were washed with $500 \mathrm{ml}$ of water followed by $500 \mathrm{ml}$ of $0.1 \mathrm{M} \mathrm{NaOH}$. Carbohydrates were covalently crosslinked to the Sepharose matrix by incubation of the beads with $25 \mathrm{ml}$ of either starch $(25 \mathrm{mg} / \mathrm{ml})$ or dextran $(50 \mathrm{mg} / \mathrm{ml})$ in $0.1 \mathrm{M} \mathrm{NaOH}$ for $20 \mathrm{~h}$ at $45^{\circ} \mathrm{C}$ with shaking. After incubation, the beads were washed with $500 \mathrm{ml}$ each of distilled water, $0.1 \mathrm{M}$ sodium acetate, $\mathrm{pH} 4.0$, and $0.1 \mathrm{M} \mathrm{NaOH}$ and then $10 \mathrm{mM}$ Tris/HCl, $\mathrm{pH} 7.2$, containing $1 \mathrm{mM}$ EDTA. The beads were stored at $4{ }^{\circ} \mathrm{C}$ in PBS containing $0.02 \%(\mathrm{w} / \mathrm{v})$ sodium azide.

\section{Preliminary binding assays}

Affinity columns with internal dimensions of $6 \mathrm{~mm} \times 70 \mathrm{~mm}$ were prepared from $1 \mathrm{ml}$ sterile plastic syringes, packed with a
$1 \mathrm{ml}$ bed volume of the affinity matrix, plugged with sterile glass wool. The columns were washed with $10 \mathrm{ml}$ of distilled water and then equilibrated with $10 \mathrm{ml}$ of SMM. Preliminary binding assays were performed to confirm binding characteristics of SF46s and SF46s(pCELBK1) to starch- and dextran-Sepharose matrices by methods described in [8]. Columns were washed with SMM to remove transiently and weakly bound cells. Bound cells were eluted from the column using $0.25 \mathrm{M}$ maltose or $10 \%(\mathrm{w} / \mathrm{v})$ dextran in SMM.

\section{Continuous affinity-based selection (CABS)}

For selection experiments, growing cultures were harvested by centrifugation, washed and resuspended in antibiotic-free SMM. Serial dilutions were performed such that the $\mathrm{R}+\mathrm{ve}$ (pCELBK1) population was diluted with the $\mathrm{R}-\mathrm{ve}$ (SF46s) population to ratios of $1: 6 \times 10^{8}$ respectively. Cells (up to $1 \times 10^{10}$ in a $25 \mathrm{ml}$ suspension) were applied to a $1 \mathrm{ml}$ affinity fermenter (starch-and dextran-Sepharose columns prepared as above) at a flow rate of $0.3 \mathrm{ml} / \mathrm{min}$. The affinity fermenter was then washed continuously with fresh, sterile SMM $(0.5 \mathrm{ml} / \mathrm{min})$ for up to $42 \mathrm{~h}$, allowing simultaneous multiplication of bound cells and removal of weakly bound bacteria. Cells were subsequently eluted from the affinity fermenter with $0.25 \mathrm{M}$ maltose in SMM. Serial dilutions were performed and aliquots plated on Luria broth agar plates containing either kanamycin and ampicillin or ampicillin alone. Colony-forming units were counted after overnight incubation at $37^{\circ} \mathrm{C}$. $\mathrm{R}+$ ve cells were identified by their ability to grow on plates containing both ampicillin and kanamycin. The $\mathrm{R}-\mathrm{ve}$ cells (SF46s) did not grow in the presence of $50 \mu \mathrm{g} / \mathrm{ml} \mathrm{kanamycin}$. Colony-forming units were compared and ratios determined. Colonies were confirmed to be either $\mathrm{R}-\mathrm{ve}(\mathrm{SF} 46 \mathrm{~s})$ or $\mathrm{R}+\mathrm{ve}$ [SF46s(pCELBK1)] by determining their individual starch-binding characteristics as described for the preliminary binding assays.

\section{Directed evolution: constitutive expression of LamB OMP on the surface of $\mathbf{R}-\mathbf{v e}$ cells}

The CABS procedure was repeated as described with the exception that $\mathrm{R}+\mathrm{ve}$ cells were omitted from the system; only $\mathrm{R}$ - ve cells $\left(1 \times 10^{9}\right.$ in $10 \mathrm{ml}$ suspension $)$ were applied to starchSepharose columns. The columns were washed continuously as described for $60 \mathrm{~h}$, after which the cells remaining bound were eluted with $0.25 \mathrm{M}$ maltose in SMM. Serial dilutions were performed and aliquots plated on Luria broth-agar plates containing ampicillin alone. After overnight incubation at $37^{\circ} \mathrm{C}$ individual colonies were assayed for constitutive expression of LamB OMP and starch-binding characteristics.

\section{Whole-cell ELISA for typing $E$. coli using monoclonal antibodies}

The method used to type individual clones for expression of the LamB OMP was adapted from that described by Abdillahi and Poolman for subtyping Neisseria [18]. Briefly, individual clones were cultured in rich media at $37^{\circ} \mathrm{C}$ to the exponential growth phase. The suspensions were adjusted to an absorbance $\left(A_{660}\right)$ of 0.05 in coating buffer (sodium bicarbonate/sodium carbonate buffer, $\mathrm{pH}$ 9.6). Thereafter, aliquots of $100 \mu \mathrm{l}$ of the bacterial suspensions in coating buffer were placed into individual wells of a series of flat-bottomed high-binding, 96-well poly(vinyl chloride) enzyme immunoassay/radioimmunoassay (EIA/RIA) microtitre plates (Costar), covered and allowed to fix to the plates overnight at $37^{\circ} \mathrm{C}$. The coated plates were washed four times with wash buffer $\left(0.5 \mathrm{M} \mathrm{NaCl} / 15 \mathrm{mM} \mathrm{KH}_{2} \mathrm{PO}_{4} /\right.$ 
$65 \mathrm{mM} \mathrm{Na}_{2} \mathrm{HPO}_{4}$ ) containing $0.05 \%$ (v/v) Tween 20. The fixed cells were then incubated with $100 \mu \mathrm{l}$ of diluted monoclonal antibodies for $2 \mathrm{~h}$ at $37^{\circ} \mathrm{C}$; monoclonal antibodies (AstraZeneca) raised against purified LamB OMP (a kind gift of Dr J. Rosenbusch, University of Basel, Basel, Switzerland) were diluted $1: 20$ in wash buffer containing $0.05 \%$ (v/v) Tween 20 and $0.5 \%$ (v/v) BSA (to block non-specific binding). After further washing as described above, $100 \mu \mathrm{l}$ of rabbit anti-mouse Ig-peroxidase conjugate (Dako) diluted 1:500 in wash buffer + Tween 20 + BSA was added to each well and the incubation repeated as above. After repeated washing as before, $200 \mu \mathrm{l}$ of freshly prepared buffered peroxidase substrate (Sigma) solution was added to each well. After $10 \mathrm{~min}$ at room temperature, the reaction was terminated by the addition of $50 \mu \mathrm{l}$ of $4 \mathrm{M} \mathrm{H}_{2} \mathrm{SO}_{4}$. Absorbances were read at $490 \mathrm{~nm}$ using a Dynex microplate reader (Dynex). The absorbances were compared with those obtained with pop6510 (a lamB-negative control strain [19]) and SF46s (R - ve) and the increased absorbance or signal was calculated. A monoclonal antibody not specific for LamB OMP or for E. coli was used to control for non-specific binding in the assay.

\section{RESULTS AND DISCUSSION}

The development of the starch-mediated model selection system described here was established with E. coli K-12 strains. Preliminary binding assays were performed to confirm the binding characteristics of $\mathrm{R}-\mathrm{ve}$ and $\mathrm{R}+\mathrm{ve}$ strains [SF46s and SF46s(pCELBK1), respectively] to starch- and dextranSepharose matrices. The E. coli strain SF46s was chosen since it lacks the periplasmic amylase (MalS) normally present in $E$. coli that otherwise degrades immobilized starch-Sepharose (D. Patel, unpublished work). This strain does not constitutively express lamB and subsequently does not bind appreciably to starchSepharose (Table 1) under the growth conditions employed. When SF46s was transformed with plasmid pCELBK1 (constitutively expressing $\operatorname{lam} B$ ), over $95 \%$ of the applied cells bound to starch-Sepharose and could be recovered specifically by elution with aqueous maltose, which competes with starch for LamB binding and thus acts as an affinity elutant. Neither strain was retained significantly by dextran-Sepharose (Table 1), which was used as a negative control. In all cases, $<5 \%$ non-specific binding was observed. The non-specific binding may be attributable to physical adsorption or entrapment of bacteria in the matrix or the affinity-fermenter support [8]. This was supported further by findings that these bacteria could not be recovered by elution with soluble carbohydrate ligands (Table 1).

Table 1 Binding characteristics of the $R-v e$ and $R+v e$ strains, SF46s and SF46s(pCELBK1)

Pure cultures of $R-v e$ and $R+$ ve cells were applied to starch- and dextran-Sepharose affinity columns. Non-specifically bound cells were washed out using SMM and thereafter bound bacteria were eluted with soluble ligand. The data presented were obtained from triplicate experiments; the average S.E.M. was $+1 \%$.

\begin{tabular}{|c|c|c|c|c|}
\hline \multirow[b]{3}{*}{ Wash/elution buffer } & \multicolumn{4}{|c|}{ Binding (\%) } \\
\hline & \multicolumn{2}{|c|}{ Starch-Sepharose } & \multicolumn{2}{|c|}{ Dextran-Sepharose } \\
\hline & $R-v e$ & $R+v e$ & $R-v e$ & $R+v e$ \\
\hline Wash with SMM & 91 & 4 & 98 & 96 \\
\hline Elution with $0.25 \mathrm{M}$ maltose in SMM & 5 & 98 & - & - \\
\hline Elution with $10 \%(\mathrm{w} / \mathrm{v})$ dextran in SMM & - & - & & \\
\hline Total recovery & 96 & 102 & 101 & 98 \\
\hline
\end{tabular}

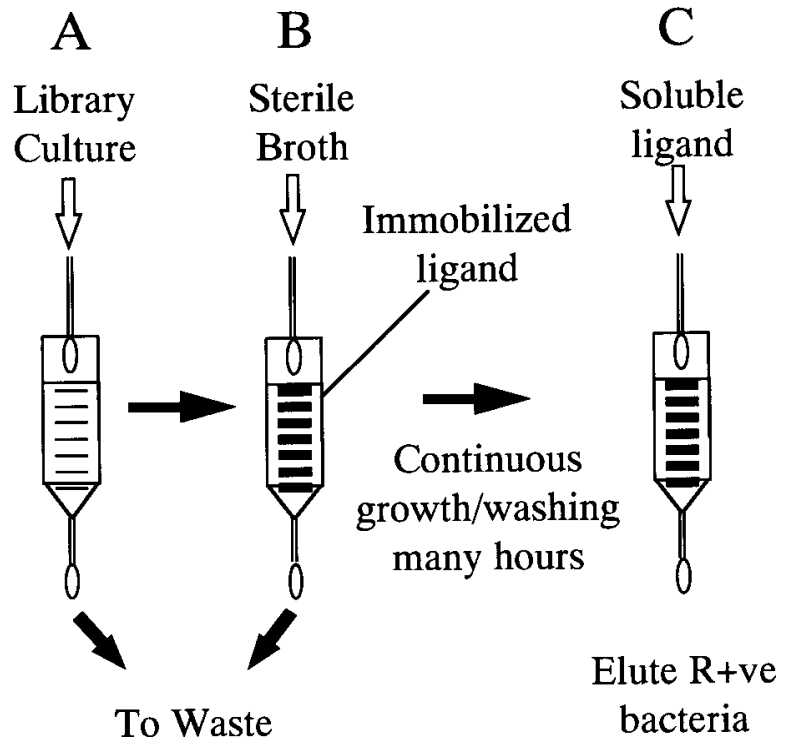

Figure 1 Schematic diagram of CABS

(A) Cultures consisting of a mixture of $\mathrm{R}+\mathrm{ve}$ and $\mathrm{R}-$ ve bacteria are applied to the affinity fermenter where $R+$ ve cells bind to the immobilized ligand. (B) The fermenter is washed continuously with sterile broth for up to $60 \mathrm{~h}$. Bound cells multiply on the matrix and unbound cells are washed out to waste. (C) Bound cells are eluted using soluble ligand.

CABS experiments were performed as described in the Materials and methods section (see Figure 1). The positiveselection experiments (Table 2 ) demonstrated that from an initial ratio of approx. 1 in $>2 \times 10^{8} \mathrm{R}+\mathrm{ve} / \mathrm{R}-\mathrm{ve}$ cells respectively, the $\operatorname{lam} B$-expressing population $(\mathrm{R}+\mathrm{ve})$ was selected for and enriched on the starch-Sepharose affinity fermenters to final ratios as high as 1:11. Enrichment factors (defined as the initial ratio/final ratio) of between 4- and 55-million-fold of the $\mathrm{R}+\mathrm{ve}$ strain were obtained. Enrichment was not achieved on control dextran-Sepharose columns (Table 3). The decrease in the final ratio of $\mathrm{R}+\mathrm{ve} / \mathrm{R}$ - ve cells observed in these experiments is not significant. These results confirm that in the positive-selection experiments using cognate immobilized ligand (starchSepharose), enrichment is mediated by the specificity of the receptor-ligand pair employed. Furthermore they demonstrate simultaneous enrichment and amplification in a simple continuous process which mimics the essential features of clonal selection.

The principle of clonal selection was demonstrated further by experiments that resulted in directed evolution. Solely $\mathrm{R}-\mathrm{ve}$ cells were applied to starch-Sepharose columns. A minor population was found to remain bound to the matrix, but elutable with maltose, after continuous selection and amplification for $60 \mathrm{~h}$. To ascertain whether these maltose-eluted cells were in fact cells trapped in the columns or specifically bound to the starch matrix, the eluted cells were plated and individual colonies were assayed for LamB OMP expression. Figure 2 illustrates the ELISA signals obtained as a result of binding of monoclonal anti-LamB OMP antibodies by pop6510 (a $\operatorname{lamB} B$-negative control), $\mathrm{R}-\mathrm{ve}, \mathrm{R}+\mathrm{ve}$ and individual clones recovered from the directed-evolution selection experiments. First and foremost, the $\mathrm{R}-\mathrm{ve}$ cells did not bind significant amounts of monoclonal anti-LamB OMP antibody, as indicated by the lack of signal (substrate-enzyme reaction); the absorbance or signal was similar 


\section{Table 2 Continuous affinity culture and selection using starch-Sepharose affinity fermenters}

Mixed populations of $R-v e$ (SF46s) and R + ve [SF46s(pCELBK1)] strains were applied to starch-Sepharose affinity fermenters. After loading, non-specifically bound cells were washed out while those cells bound inside the affinity fermenter were allowed to grow under continuous flow conditions. The data presented demonstrate selection and amplification achieved after the incubation times shown, with SMM containing glycerol as shown. Thereafter bound cells were eluted with $0.25 \mathrm{M}$ maltose in SMM. Enrichment is defined as the initial ratio/final ratio.

\begin{tabular}{|c|c|c|c|c|c|c|c|}
\hline \multirow[b]{2}{*}{ Incubation time/medium } & \multicolumn{3}{|l|}{ Applied } & \multicolumn{3}{|l|}{ Eluted } & \multirow[b]{2}{*}{ Enrichment } \\
\hline & Total $R+$ ve cells & Total $R$-ve cells & Initial ratio $(R+v e / R-v e)$ & Total $R+$ ve cells & Total $\mathrm{R}-$ ve cells & Final ratio $(R+v e / R-v e)$ & \\
\hline $24 \mathrm{~h} / \mathrm{SMM}+0.2 \%$ glycerol & 2100 & $4.8 \times 10^{9}$ & $1: 2.3 \times 10^{6}$ & $8.6 \times 10^{7}$ & $4.2 \times 10^{8}$ & $1: 5$ & $4.6 \times 10^{5}$ \\
\hline $45 \mathrm{~h} / \mathrm{SMM}+2.5 \%$ glycerol & 3300 & $4.2 \times 10^{9}$ & $1: 1.3 \times 10^{6}$ & $4.6 \times 10^{8}$ & $7.4 \times 10^{8}$ & $1: 1.6$ & $8.1 \times 10^{5}$ \\
\hline $45 \mathrm{~h} / \mathrm{SMM}+2.5 \%$ glycerol & 3300 & $4.2 \times 10^{9}$ & $1: 1.3 \times 10^{6}$ & $8.1 \times 10^{7}$ & $1.2 \times 10^{8}$ & $1: 1.5$ & $8.7 \times 10^{5}$ \\
\hline $36 \mathrm{~h} / \mathrm{SMM}+0.2 \%$ glycerol & 22 & $4.0 \times 10^{9}$ & $1: 1.8 \times 10^{8}$ & $3.3 \times 10^{7}$ & $1.0 \times 10^{9}$ & $1: 30$ & $6.0 \times 10^{6}$ \\
\hline $36 \mathrm{~h} / \mathrm{SMM}+0.2 \%$ glycerol & 22 & $4.0 \times 10^{9}$ & $1: 1.8 \times 10^{8}$ & $3.4 \times 10^{7}$ & $1.5 \times 10^{9}$ & $1: 44$ & $4.1 \times 10^{6}$ \\
\hline $36 \mathrm{~h} / \mathrm{SMM}+0.2 \%$ glycerol & 11 & $3.6 \times 10^{9}$ & $1: 3.3 \times 10^{8}$ & $1.8 \times 10^{6}$ & $1.5 \times 10^{8}$ & $1: 83$ & $4.0 \times 10^{6}$ \\
\hline $36 \mathrm{~h} / \mathrm{SMM}+2.5 \%$ glycerol & 14 & $4.4 \times 10^{9}$ & $1: 3.1 \times 10^{8}$ & $4.7 \times 10^{7}$ & $5.3 \times 10^{8}$ & $1: 11$ & $2.8 \times 10^{7}$ \\
\hline $42 \mathrm{~h} / \mathrm{SMM}+2.5 \%$ glycerol & 20 & $1.2 \times 10^{10}$ & $1: 6.0 \times 10^{8}$ & $3.0 \times 10^{7}$ & $1.2 \times 10^{9}$ & $1: 40$ & $1.5 \times 10^{7}$ \\
\hline $42 \mathrm{~h} / \mathrm{SMM}+2.5 \%$ glycerol & 20 & $1.2 \times 10^{10}$ & $1: 6.0 \times 10^{8}$ & $1.5 \times 10^{8}$ & $1.7 \times 10^{9}$ & $1: 11$ & $5.5 \times 10^{7}$ \\
\hline
\end{tabular}

Table 3 Continuous affinity culture and selection using control dextran-Sepharose affinity fermenters

Mixed populations of $\mathrm{R}-\mathrm{ve}$ (SF46S) and $\mathrm{R}+\mathrm{ve}$ [SF46s(pCELBK1)] strains were applied to dextran-Sepharose affinity fermenters. After affinity selection and amplification under continuous flow conditions for $24 \mathrm{~h}$ with SMM containing $0.2 \%$ glycerol, bound cells were eluted with $0.25 \mathrm{M}$ maltose in SMM. Enrichment is defined as initial ratio/final ratio.

\begin{tabular}{|c|c|c|c|c|c|c|}
\hline \multicolumn{3}{|l|}{ Applied } & \multicolumn{3}{|l|}{ Eluted } & \multirow[b]{2}{*}{ Enrichment } \\
\hline Total $R+$ ve cells & Total $R$-ve cells & Initial ratio $(R+v e / R-v e)$ & Total $R+$ ve cells & Total $R$-ve cells & Final ratio $(R+v e / R-v e)$ & \\
\hline $\begin{array}{l}1.4 \times 10^{3} \\
1.0 \times 10^{3} \\
1.0 \times 10^{3}\end{array}$ & $\begin{array}{l}4.4 \times 10^{9} \\
5.0 \times 10^{9} \\
5.0 \times 10^{9}\end{array}$ & $\begin{array}{l}1: 3.1 \times 10^{6} \\
1: 5.0 \times 10^{6} \\
1: 5.0 \times 10^{6}\end{array}$ & $\begin{array}{r}<10 \\
20 \\
<10\end{array}$ & $\begin{array}{l}1.6 \times 10^{8} \\
5.7 \times 10^{8} \\
5.3 \times 10^{7}\end{array}$ & $\begin{array}{l}1: 1.6 \times 10^{7} \\
1: 2.9 \times 10^{7} \\
1: 5.3 \times 10^{6}\end{array}$ & $\begin{array}{l}0.2 \\
0.2 \\
0.9\end{array}$ \\
\hline
\end{tabular}

to background noise. Background noise is interpreted as the absorbance obtained from the substrate-enzyme reaction for pop6510 cells. Furthermore, neither the $\mathrm{R}-\mathrm{ve}$ cells, $\mathrm{R}+\mathrm{ve}$ cells nor the individual clones bound control monoclonal antibody; the absorbance was equivalent to background noise. However, the ELISA signal obtained for the $\mathrm{R}+\mathrm{ve}$ cells was between two and seven times greater than that produced by $\mathrm{R}-\mathrm{ve}$ cells, indicating that the signal obtained was a result of anti-LamB OMP antibody binding to the cell-surface-expressed LamB OMP. Whereas the signal obtained from clones 1, 4, 6 and 7 was not greater than that of the $\mathrm{R}-$ ve cells, the signal obtained from clones 2, 3 and 5 exceeded those of $\mathrm{R}-\mathrm{ve}$ cells. The increased signals (two to nine times greater) were comparable with, if not better than, those obtained from the $\mathrm{R}+\mathrm{ve}$ cells. The resultant increased signal from these clones indicated that they constitutively express LamB OMP. A sub-population of an originally pure population of $\mathrm{R}$-ve cells (not constitutively expressing LamB OMP) had become constitutive expressors, presumably facilitated by spontaneous mutation. Continuous selection and exposure to the starch matrix had resulted in selective retention of cells exhibiting constitutive expression of the chromosomal gene (normally requiring induction). This assumption was confirmed by determining the ability of individual clones from the directed-evolution-selected pool to bind to starch-Sepharose (Figure 3). Whereas pre-CABS-selected $\mathrm{R}-\mathrm{ve}$ cells did not significantly bind to starch-Sepharose, as expected, $50 \%$ of the pool recovered post-CABS did bind to the affinity matrix.

The levels of LamB protein production and binding characteristics of the individual clones are compared in Figure 4. A number of the clones (clones 2, 3 and 5) show an increased ELISA signal, indicating up-regulation of the $\operatorname{lam} B$ gene product.
However, the others (clones 1, 4, 6 and 7) show little increase in ELISA signal in comparison with the parent $\mathrm{R}-$ ve strain, yet two of these (clones 1 and 4) show increased starch binding compared with the parental strain. This observation is not indicative of any up-regulation of the $\operatorname{lam} B$ gene product. However, it may be attributable to an increased affinity for starch of either a mutated $\operatorname{lam} B$ gene product or other unknown gene product(s). Such mutations could have either been present in the applied 'clonal' population or have occurred during the course of the culture process. Given that $10^{9}$ organisms were initially loaded and that the estimated spontaneous mutation rate in E. coli is one mutation per 300 chromosomal replications, it is clear that a large number of mutant organisms were available from which to select [20].

The CABS approach differs significantly from the batch process described by Ferenci and Lee [8]. In order to enrich for a starch-binding phenotype Ferenci and Lee used 10 iterative cycles [21]. Each cycle consisted of first loading bacteria on to the immobilized starch, washing of unbound bacteria and maltose elution under non-growth conditions. The eluted bacteria must subsequently be amplified by growth in batch before application to the next cycle, resulting in a process taking approx. 1 day per cycle. In contrast, the CABS system is a continuous and rapid process, requiring little hands-on time. Bound cells are subjected to simultaneous amplification and selection (for binding) allowing enrichment factors of many million-fold to be achieved within $48 \mathrm{~h}$. Thus the combination of continuous washout and affinity chromatography that defines the CABS approach provides the basis for the large enrichment factors observed.

Whereas the display of peptide and antibody libraries on the surface of phages [2,3,22-25] has provided a powerful means of making antibodies of predefined specificity, increasing interest 


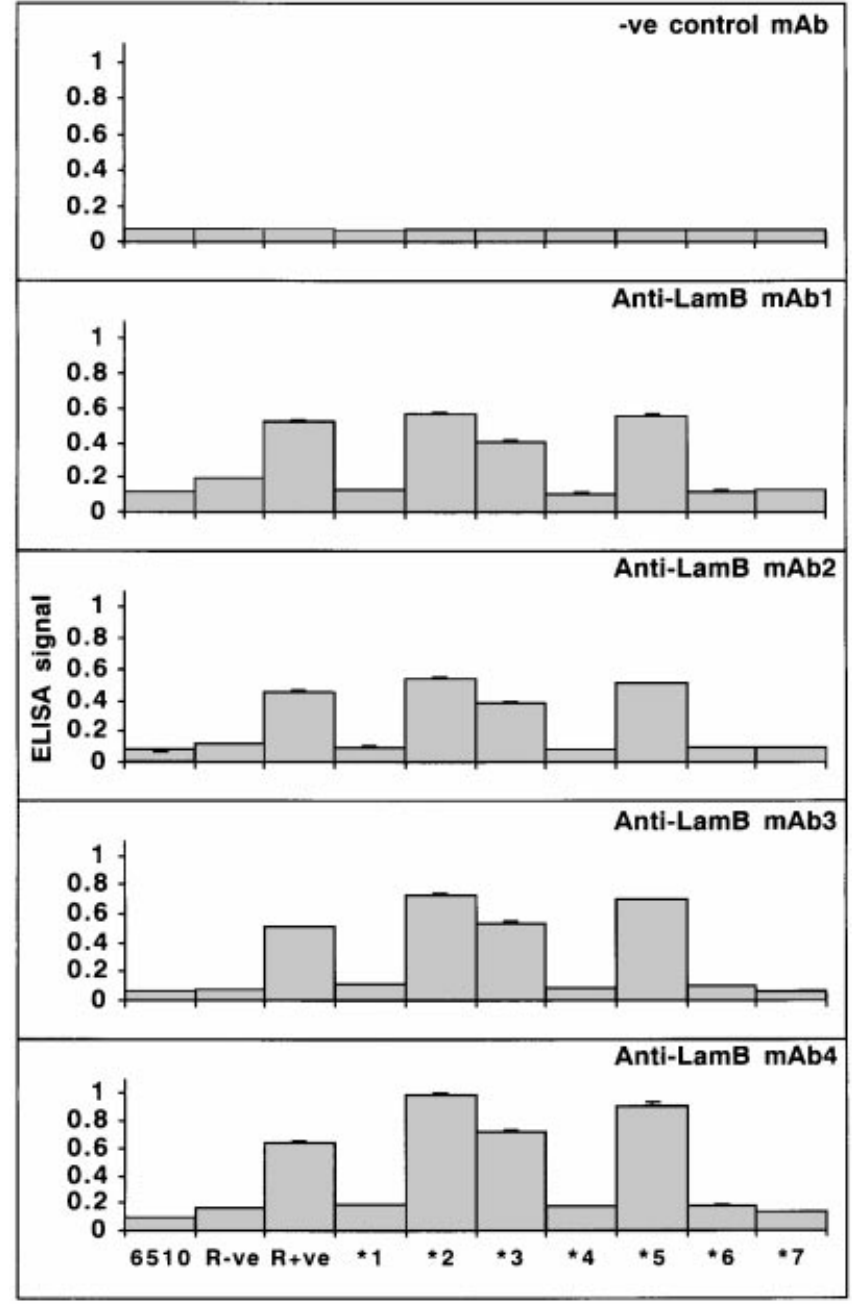

Figure 2 ELISA signals obtained for pop6510 (lamB-negative control), $\mathbf{R}-\mathbf{v e}$ cells, $\mathbf{R}+\mathbf{v e}$ cells and individual clones $\left({ }^{*} 1-{ }^{*} 7\right)$ from directedevolution experiments

Absorbances $\left(A_{660}\right)$ obtained after incubation of cells with monoclonal anti-LamB OMP antibody (mAbs 1-4), polyclonal peroxidase-conjugated antibody and buffered peroxidase substrate. Means \pm S.E.M. from experiments performed in triplicate are shown.

has been shown in the display of such libraries on the surface of Gram-negative bacteria [5,6,26-29], and more recently Grampositive bacteria $[6,30,31]$. To this purpose, our approach to simultaneous screening and amplification may be used to sort through bacterial libraries and enrich for a natural or engineered population expressing a specific surface receptor. There are some obvious limitations to the system described here, namely production of large libraries of peptide sequence on the surface of $E$. coli and the requirement that $E$. coli should not bind appreciably to (or degrade) the immobilized ligand of interest. Yet there is no obvious need to have a soluble ligand to effect affinity elution, as the required cells can be simply grown off the matrix. In addition, this technology eliminates the need for repeated elution, plating, re-culturing and rounds of selection that are necessary for systems based on phage display; bacterial display systems have the advantage of being self-replicative, enabling direct multiplication of cells under conditions of stringent selection for a desired binding phenotype, as demonstrated here. The simple CABS technique described may be applied to various applications such

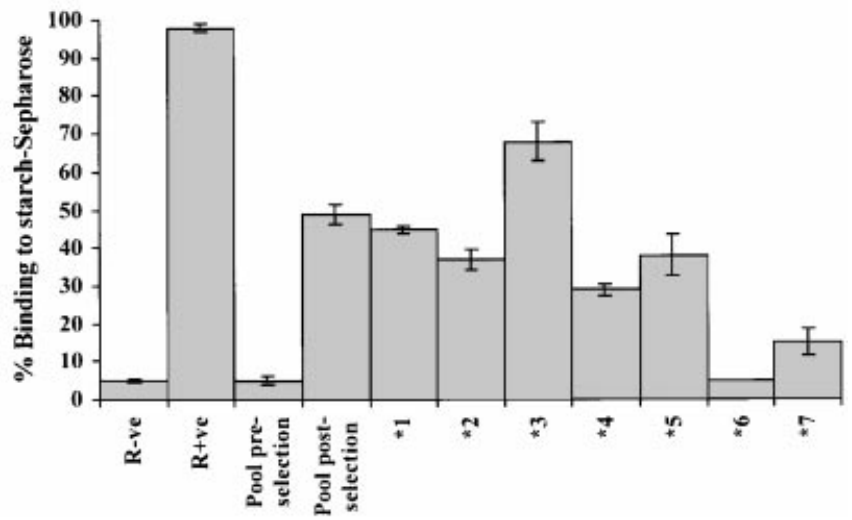

Figure 3 Binding characteristics of maltose-eluted cells from directedevolution experiments using an initially $\mathbf{R}-$ ve applied cell pool

The starch-binding characteristics of the unselected pool, post-selection pool and axenic cultures of individual clones $\left({ }^{*} 1-{ }^{\star} 7\right.$, obtained at random from the post-selection pool) were determined. Results of binding of $R-v e$ and $R+v e$ control cultures are also shown. The bars represent the mean percentage bound to a starch-Sepharose column in the standard assay ( \pm S.E.M.; from at least three experiments).

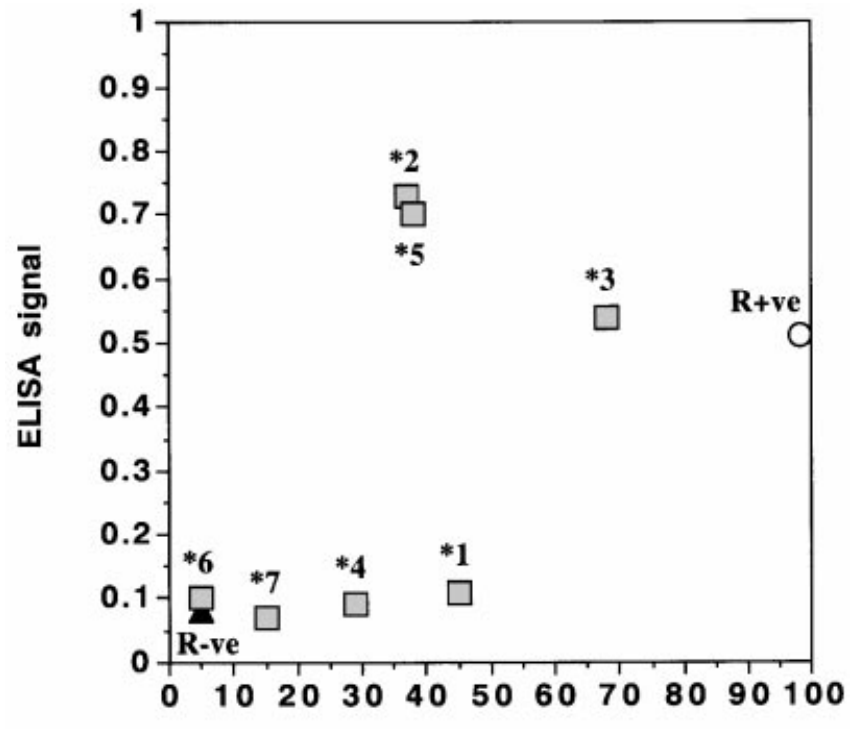

$\%$ Binding to starch-Sepharose

Figure 4 Levels of LamB protein production (ELISA signals) and starchSepharose binding characteristics of maltose-eluted cells from $R-v e$ directed-evolution experiments

The ELISA signal data set used here was obtained with anti-LamB monoclonal antibody 3. A similar trend was seen with anti-LamB monoclonal antibodies 1, 2 and 4. Data points for $R-v e$ and $R+$ ve precultures are also shown.

as the identification of adhesins, the development of live bacterial vaccines, the screening of peptide and antibody libraries, the production of cellular adsorbents and the preparation of novel whole-cell biocatalysts [5,6,32-34]. Developments in the display of antibody fragments on the surface of $E$. coli combined with the powerful clonal selection system described here could lead to a new alternative technology for the production of proteins with binding activities similar to monoclonal antibodies in very short time scales. For example, it is possible to display a single-chain 
antibody fragment on the surface of $E$. coli using the neisserial $\beta$ core autotranporter system [35]. Thus it should be possible to produce a library of $\mathrm{scFv}$ fragments using this display system, as has been reported extensively in the phage-display field [2-4,22,24]. This surface-displayed library would then be loaded on to a column containing the immobilized ligand of interest and the CABS process carried out. Binders would be enriched in the same way that our model system enriched for starch-binding cells. The selected cells would then be recovered from the saturated matrix by either elution with soluble ligand or removal of the matrix, or may simply be allowed to grow off the support (replicating bacteria would eventually saturate the available immobilized-ligand sites, and as these bacteria continue to divide their progeny would be washed out of the affinity fermenter).

Evolution of new or improved binding properties could be facilitated by applying directed mutagenesis to the gene of interest. The powerful technique of DNA shuffling described by Stemmer [36] could be used to generate large repertoires of variant sequences which would then be ligated into a vector for surface display. Thus a large library consisting of variations in the gene of interest would be created. This library would then be subjected to the CABS approach. It should also be possible to increase the rate of random mutagenesis, leading to the generation of even larger repertoires by use of strains which show a higherthan-normal mutation rate, e.g. mut $^{-}$strains [37].

The CABS approach could also be used for selection from peptide-display libraries. For example, unknown epitopes could be identified by immobilizing the antibody of interest in the affinity fermenter and applying the CABS procedure to a peptidedisplay library such as that using the flagellum protein [38].

In summary, selection and amplification of a specific population from a mock surface-display library can be achieved using CABS, as demonstrated here. Up to 55 million-fold enrichment was obtained using the simple strategy described. In addition, where lesser dilutions of the $\mathrm{R}+$ ve cells were used (Table 2), the final ratios of $\mathrm{R}+$ ve to $\mathrm{R}$ - ve cells obtained were better than $1: 2$; this was achieved by allowing selection and enrichment to continue for a longer duration (prior to eventual blockage of the column). The fact that mutants constitutively expressing $\operatorname{lam} B$ were isolated from a wild-type (non-binding) population further demonstrates the power of this simple system, selecting a population with enhanced binding characteristics. The CABS methodology has considerable potential as a biopanning tool.

This work was supported by the Biotechnology and Biological Sciences Research Council LINK Protein Engineering Programme (GR/J21040) in collaboration with AstraZeneca. M.J.D. was supported by a Royal Society Industry Fellowship (B/94/IF/193). We thank Dr W. Boos, University of Konstanz, Konstanz, Germany, for the E. coli strain SF46s, and Dr J. Rosenbusch, University of Basel, Basel, Switzerland, for purified LamB. We also thank Dr B. G. MacDonald for technical assistance with matrix preparation during the preliminary stages of the project.

\section{REFERENCES}

1 Köhler, G. and Milstein, C. (1975) Continuous cultures of fused cells secreting antibody of predefined specificity. Nature (London) 256, 495-497

2 Clackson, T., Hoogenboom, H. R., Griffiths, A. D. and Winter, G. (1991) Making antibody fragments using phage display libraries. Nature (London) 352, 624-628

3 Marks, C. and Marks, J. D. (1996) Phage libraries - a new route to clinically useful antibodies. N. Engl. J. Med. 335, 730-733

4 Winter, G. and Milstein, C. (1991) Man-made antibodies. Nature (London) $\mathbf{3 4 9}$ 293-299

5 Georgiou, G., Stathopoulos, C., Daugherty, P. S., Nayak, A. R., Iverson, B. L. and Curtiss, III, R. (1997) Display of heterologous proteins on the surface of microorganisms: from the screening of combinatorial libraries to live recombinant vaccines. Nat. Biotechnol. 15, 29-34
6 Ståhl, S. and Uhlén, M. (1997) Bacterial surface display: trends and progress. Trends Biotechnol. 15, 185-192

7 Kadner, R. J. and Bassford, P. J. (1978) The role of the outer membrane in active transport. In Bacterial Transport (Rosen, B. P., ed.), pp. 413-462, Marcel Dekker, New York

8 Ferenci, T. and Lee, K.-S. (1982) Directed evolution of the lambda receptor of Escherichia coli through affinity chromatography selection. J. Mol. Biol. 160, 431-444

9 Ferenci, T. (1984) Genetic manipulation of bacterial surfaces through affinitychromatographic selection. Trends Biochem. Sci. 9, 44-48

10 Szmelcman, S. and Hofnung, M. (1975) Maltose transport in Escherichia coli K-12: involvement of the bacteriophage lambda receptor. J. Bacteriol. 124, 112-118

11 Klebba, P. E., Hofnung, M. and Charbit, A. (1994) A model of maltodextrin transport through the sugar-specific porin, LamB, based on deletion analysis. EMBO J. $\mathbf{1 3}$ 4670-4675

12 Dumas, F., Koebnik, R., Winterhalter, M. and van Gelder, P. (2000) Sugar transport through maltoporin of Escherichia coli. J. Biol. Chem. 275, 19747-19751

13 Ferenci, T. and Stretton, S. (1989) Cysteine-22 and cysteine-38 are not essential for the functions of maltoporin (LamB protein). FEMS Microbiol. Letts. 61, 335-340

14 Chang, A. C. Y. and Cohen, S. N. (1978) Construction and characterization of amplifiable multicopy DNA cloning vehicles derived from the P15A cryptic miniplasmid. J. Bacteriol. 134, 1141-1156

15 Rose, R. E. (1988) The nucleotide-sequence of pACYC177. Nucleic Acids Res. 16, 356

16 Miller, J. H. (1972) Experiments in Molecular Genetics, Cold Spring Harbor Press, Cold Spring Harbor

17 Sunberg, L. and Porath, J. (1974) Preparation of adsorbents for biospecific affinity chromatography. J. Chromatogr. 90, 87-98

18 Abdillahi, H. and Poolman, J. T. (1987) Whole-cell ELISA for typing Neisseria meningitidis with monoclonal antibodies. FEMS Microbiol. Lett. 48, 367-371

19 Bouges-Bocquet, B., Villaroya, H. and Hofnung, M. (1984) Linker mutagenesis in the gene of an outer membrane protein of Escherichia coli, LamB. J. Cell. Biochem. 24, 217-228

20 Drake, J. W., Charlesworth, B., Charlesworth, D. and Crow, J. F. (1998) Rates of spontaneous mutation. Genetics 148, 1667-1686

21 Ferenci, T. and Lee, K.-S. (1983) Isolation, by affinity chromatography, of mutant Escherichia coli cells with novel regulation of lamB expression. J. Bacteriol. 154 984-987

22 McCafferty, J., Griffiths, A. D., Winter, G. and Chiswell, D. J. (1990) Phage antibodies: filamentous phage displaying antibody variable domains. Nature (London) 348, 552-554

23 Scott, J. K. and Smith, G. P. (1990) Searching for peptide ligands with an epitope library. Science 249, 386-390

24 Griffiths, A. D., Williams, S. C., Hartley, O., Tomlinson, I. M., Waterhouse, P., Crosby, W. L., Kontermann, R. E., Jones, P. T., Low, N. M., Allison, T. J. et al. (1994) Isolation of high affinity human antibodies directly from large synthetic repertoires. EMBO J. 13, 3245-3260

25 Sheets, M. D., Amersdorfer, P., Finnern, R., Sargent, P., Lindqvist, E., Schier, R., Hemingsen, G., Wong, C., Gerhart, J. C. and Marks, J. D. (1998) Efficient construction of a large nonimmune phage antibody library: the production of highaffinity human single-chain antibodies to protein antigens. Proc. Natl. Acad. Sci. U.S.A. 95, 6157-6162

26 Better, M., Chang, C. P., Robinson, R. R. and Horwitz, A. H. (1988) Escherichia coli secretion of an active chimeric antibody fragment. Science 40, 1041-1043

27 Francisco, J. A., Campbell, R., Iverson, B. L. and Georgiou, G. (1993) Production and fluorescent-activated cell sorting of Escherichia coli expressing a functional antibody fragment on the external surface. Proc. Natl. Acad. Sci. U.S.A. 90, 10444-10448

28 Jung, H.-C., Lebeault, J.-M. and Pan, J.-G. (1998) Surface display of Zymomonas mobilis levansucrase by using the ice-nucleation protein of Pseudomonas syringae. Nat. Biotechnol. 16, 576-580

29 Lattemann, C. T., Maurer, J., Gerland, E. and Meyer, T. F. (2000) Autodisplay: functional display of active $\beta$-lactamase on the surface of Escherichia coli by the AIDA-I autotransporter. J. Bacteriol. 182, 3726-3733

30 Gunneriusson, E., Samuelson, P., Uhlén, M., Nygren, P.-A and Ståhl, S. (1996) Surface display of a functional single-chain Fv antibody on Staphylococci. J. Bacteriol. 178, 1341-1346

31 Robert, A., Samuelson, O., Andréoni, C., Bächi, T., Uhlén, M., Binz, H., Nguyen, T. N. and Ståhl, S. (1996) Surface display on staphylococci: a comparative study. FEBS Lett. 390, 327-333

32 Pedersen, H., Hölder, S., Sutherlin, D. P., Schwitter, U., King, D. S and Schultz, P. G. (1998) A method for directed evolution and functional cloning of enzymes. Proc. Natl. Acad. Sci. U.S.A. 95, 10523-10528 
33 Li, M. (2000) Applications of display technology in protein analysis. Nat. Biotechnol. 18, $1251-1256$

34 Olsen, M. J., Stephens, D., Griffiths, D., Daugherty, P., Georgiou, G. and Iverson, B. L. (2000) Function-based isolation of novel enzymes from a large library. Nat. Biotechnol. 18, 1071-1074

35 Veiga, E., de Lorenzo, V. and Fernandez, L. A. (1999) Probing secretion and translocation of a beta-autotransporter using a reporter single-chain Fv as a cognate passenger domain. Mol. Microbiol. 33, 1232-1243

Received 20 February 2001/17 May 2001; accepted 8 June 2001
36 Stemmer, W. P. C. (1994) Rapid evolution of a protein in vitro by DNA shuffling. Nature (London) 370, 389-391

37 LeClerc, J. E., Li, B., Payne, W. L. and Cebula, T. A. (1996) High mutation frequencies among Escherichia coli and Salmonella pathogens. Science 274, 1208-1211

38 Lu, Z. J., Murray, K. S., Vancleave, V., Lavallie, E. R., Stahl, M. L. and McCoy, J. M. (1995) Expression of thioredoxin random peptide libraries on the Escherichia coli cell-surface as functional fusions to flagellin - a system designed for exploring protein-protein interactions. BioTechnology 13, 366-372 